\title{
Black yeasts from the slope sediments of Bay of Bengal: phylogenetic and functional characterization
}

\author{
Kutty $\mathrm{SN}^{1}$, Lawman $\mathrm{D}^{2}$, Singh $\mathrm{ISB}^{3}$ and Philip $\mathrm{R}^{1 *}$ \\ ${ }^{1}$ Department of Marine Biology, Microbiology and Biochemistry, School of Marine Sciences, Cochin University of \\ Science and Technology, Fine Arts Avenue, Kochi- 682016. \\ ${ }^{2} 1328$ Barkley Road, Telford, TN 37690-2235 USA \\ ${ }^{3}$ National Centre for Aquatic Animal Health, Cochin University of Science and Technology, Fine arts avenue, Cochin- \\ 16
}

Kutty SN, Lawman D, Singh ISB, Philip R 2013 - Black yeasts from the slope sediments of Bay of Bengal: phylogenetic and functional characterization. Mycosphere 4(3), 346-361, Doi 10.5943/mycosphere/4/3/1

\begin{abstract}
Occurrence of black yeasts in the slope sediments of Bay of Bengal was investigated during FORV Sagar Sampada cruises 236 and 245. The black yeast population was found to be very scanty in the area and the isolates could be obtained from $200 \mathrm{~m}$ to $1000 \mathrm{~m}$ depth regions in the slope sediments. The isolates were identified as Hortaea werneckii by Internal Transcribed Spacer (ITS) sequencing. The biodegradation potential of these strains was found to be very high with all the strains exhibiting protease, lipase and amylase production. The optimum growth conditions were $\mathrm{pH} 8$, salinity $30 \mathrm{ppt}$ and temperature $30^{\circ} \mathrm{C}$. The pigment melanin, in these organisms was identified to be of dihydroxynaphthalene type by NMR. The melanin was found to exhibit inhibitory activity against different human and fish pathogens. Melanin degrading enzyme could also be extracted from these organisms.
\end{abstract}

Key words - Antibacterial - Black yeasts - Dihydroxynaphthalene - Hortaea werneckii - Marine Melanin

\section{Introduction}

Black yeasts are a melanised group of fungi belonging to divergent orders of Ascomycetes (De Hoog \& Mcginnis, 1987). Van Uden and Castelo-Branco (1963) have reported the presence of black yeasts from Pacific sub surface waters and deep waters of Loma Trough, off San Diego. Also van Uden and Ahearn (1963) did quantitative studies on yeasts present in surface and deep water samples from a fresh water body (Douglas Lake, Michigan) which revealed the presence of black yeasts. Ascomycetous black yeasts show adaptations to a wide array of environmental conditions. Factors which are of ecological significance include the presence of melanin and carotene, formation of thick walls and meristematic growth, presence of yeast-like phase, additional forms of conidiogenesis, thermo and osmotolerance, adhesion, hydro-phobicity, production of extracellular polysaccharides, siderophores and acidic or alkaline secondary metabolites (De Hoog, 1993).

Melanin is a common term used for dark brown to black pigments of high molecular mass formed by oxidative polymerization of phenolic compounds usually complexed with protein and carbohydrates. Fungal melanins occur in the cell wall or as extracellular polymers formed enzymatically or by auto oxidation (SN Kutty, 2010). The phenolic compounds from which the fungal melanins are derived include tyrosine via 3, 4-dihydroxyphenylalanine (DOPA) in some 
groups of fungi, $\gamma$-glutaminyl-3,4-dihydroxy-benzene or catechol in Basidiomycetes, and 1,8dihydroxynaphthalene (DHN) in Ascomycetes and related asexual fungi. Melanins formed by DHN pathway are of particular interest, since they reportedly protect fungi against a number of environmental factors. Melanin preparations are widely used in dermatology and cosmetology. Paramonov et al. (2002) studied the dependence of photoprotective activity of 1, 8dihydroxynaphthalene melanin using the black yeast like fungus Aureobasidium pullulans as the source of melanin. The application of melanin to skin included photoprotection, photosensitization and photoburn. Studies on Hortaea werneckii, Trimmatostroma salinum, Phaeotheca triangularis and Phyllosticta capitalensis showed the presence of DHN melanin (Kogej et al., 2004 and Suryanarayanan et al., 2004). Melanized fungi are more resistant to environmental factors than their non-melanized albino mutants or other normally non-melanized fungi (Butler et al., 2005). Melanin has diverse functions (Nosanchuk and Casadevall, 2006) i.e., sexual display and camouflage, colouration in black/ red hair and defence. They also serve as energy transducers and affect cellular integrity. Black yeast strains isolated from salt pans at the Adriatic coast were identified as Hortaea werneckii, Phaeotheca triangularis and Aureobasidium pullulans. Recently it became evident that melanized fungi, so far described only in the crystallization pond of Adriatic salterns within the season of salt production can be considered as a new group of eukaryotic halophiles (GundeCimerman et al., 2000, Butinar et al., 2005). At the highest environmental salinities, melanized fungi represented $85-100 \%$ of the total isolated mycobiota, but with lowering salinities they were partially replaced by non-melanized fungi and, at the end of the season, with $\mathrm{NaCl}$ concentrations below 5\%, they were detected only occasionally. Eukaryotic halophilic microorganisms are poorly investigated and only little is known about their adaptation to growth at extremely hypersaline conditions (Petrovic et al., 2002).

After the identification of the black yeast, Hortaea werneckii as the dominant fungal species in hypersaline waters on three continents; it represents a new model organism for studying the mechanisms of salt tolerance in eukaryotes. Ultrastructural studies of the Hortaea werneckii cell wall have shown that it synthesizes dihydroxynaphthalene (DHN) melanin under both saline and non-saline growth conditions. However, melanin granules in the cell wall are organized in a saltdependent way, implying the potential osmoprotectant role of melanin. Even Hortaea werneckii grown in high $\mathrm{NaCl}$ concentration maintain very low intracellular amounts of potassium and sodium, demonstrating the sodium-excluder characteristic of this organism (Gunde-Cimerman and Plemenitas, 2006). Studies by Kogej et al. (2006) revealed that hypersaline conditions induce changes in cell-wall melanisation and colony structure in a halophilic and a xerophilic black yeast species of the genus Trimmatostroma. They were able to adapt to hypersaline growth conditions, even though their growth patterns show distinct adaptation to their natural ecological niches. Kogej et al. (2007) showed that in Hortaea werneckii, melanisation is effective in reducing the permeability of its cell wall to its major compatible solute glycerol, which might be one of the features that help it to tolerate a wide range of salt concentrations. Hortaea werneckii is an extremely halotolerant eukaryotic microorganism and thus a promising source of transgenes for improvement of osmotolerance in industrially important yeasts, as well as in crops (Plemenitas et al., 2008).

\section{Materials and Methods}

\section{Study area and collection of sediment samples}

The study area was confined to the east coast of Indian peninsula, specifically the continental slope of Bay of Bengal. The area covered was from Karaikkal to Paradip in the Bay of Bengal. Collections were made from 200, 500 and $1000 \mathrm{~m}$ depth regions. Sediment samples were collected onboard Fisheries and Oceanographic Research Vessel (FORV) Sagar Sampada of CMLRE, Ministry of Earth Sciences, Government of India using Smith McIntyre grab. Sample collection was done during cruises Cruises $\neq 236$ (July, 2005) and 245 (July, 2006) from Bay of Bengal. Sediment sample for microbial analysis was transferred aseptically into sterile 
polythene bags.

\section{Isolation of black yeasts}

Approximately $30 \mathrm{~g}$ sediment sample was transferred into $100 \mathrm{ml}$ sterile sea water and kept on a magnetic shaker for 10 minutes. $1 \mathrm{ml}$ slurry was spread plated onto malt- yeast- glucosepeptone agar (Wickerham, 1951) supplemented with chloramphenicol $(200 \mathrm{mg} / \mathrm{l})$. The plates were incubated at $17 \pm 2{ }^{\circ} \mathrm{C}$ for 14 days. Enumeration was done and all the colonies were isolated into malt extract agar slants. Isolates were purified by repeated streaking on malt extract agar plates and stored in soft agar vials overlaid with sterile liquid paraffin. Besides, morphological analyses, the isolates were tested for fermentation/oxidation, production of starch like substances, nitrate assimilation, Diazonium Blue B reduction, urea hydrolysis, presence of pigments, casein and tyrosine decomposition and potassium nitrate assimilation. Based on morphological and biochemical characteristics the isolates were identified up to generic level.

\section{Molecular identification of black yeasts}

The isolates were identified using molecular techniques by extracting genomic DNA and sequencing of Internal Transcribed Spacer (ITS) region as per Harju et al. (2004). ITS primers (Forward ITS 1-5' TCC GTA GGT GAA CCT GCG G 3' and Reverse ITS 4- 5' TCC TCC GCT TAT TGA TAT GC 3') by White et al. (1990) which amplify a fragment of approximately 580 bp containing the ITS $1,5.8 \mathrm{~S}$ and ITS 2 regions were used. The amplification reaction was performed by using a DNA Thermal cycler (Eppendorf). After an initial denaturation at $95^{\circ} \mathrm{C}$ for 5 minutes, amplification was made through 30 cycles, each consisting of a denaturation at $94^{\circ} \mathrm{C}$ for 1 minute, annealing at $56^{\circ} \mathrm{C}$ for 45 seconds, extension at $72^{\circ} \mathrm{C}$ for 1 minute and a final extension at $72^{\circ} \mathrm{C}$ for 10 minutes. Nucleotide sequencing was performed using ABI PRISM 3700 Big Dye Sequencer at Chromous Biotech, Bangalore. The sequences were matched with the GenBank database using the Basic Local Alignment Search Tool (BLAST) algorithm (Altschul et al., 1990) at NCBI (www.ncbi.nlm.nih.gov). The sequences were multiple aligned using Clustal W (Thompson et al., 1994) and the aligned ITS- rDNA gene sequences were used to construct a phylogenetic tree using the neighbour-joining (NJ) method (Saitou and Nei, 1987) of MEGA 4.1 package (Tamura et al., 2007). Bootstrap analysis was done based on 1000 replicates. Similarity matrix and genetic distance between sequences was calculated. The number of base substitutions per site of the sequence was analysed using Bio Edit Sequence Alignment Editor. Similarity matrix of the sequence was scored using MEGA 4.1 and the distance between the strains was determined based on the pair wise analysis.

\section{Hydrolytic enzyme production}

The isolates were tested for the production of enzymes i.e., amylase (starch 1\%), lipase (tributyrin 1\%), protease (gelatin 2\%), urease (urea 2\%), aryl sulphatase, ligninase (methylene blue $2 \%$ ), cellulase (carboxy methyl cellulose 1\%), DNAse (DNA $2 \%$ ), pectinase (pectin 1\%) and chitinase (colloidal chitin 5\% w/v). Nutrient agar supplemented with the corresponding substrates was used for the enzyme assay. Clearing zone on the plates was regarded as positive except for urease and aryl sulfatase. In the case of protease and pectinase, plates were flooded with mercuric chloride and cetavlon respectively and the clearing zone was noted. For urease, development of alkaline $\mathrm{pH}$ due to the release of ammonia was noted by incorporating phenol red in the medium. In the case of aryl sulfatase a pink coloration of the medium around the colony due to the release of phenolphthalein from phenolphthalein sulfate was noted as positive.

\section{Optimum physico-chemical conditions for growth}

\section{Preparation of inoculum}

The black yeast isolates were streaked on to malt extract agar slants, incubation was done at 
room temperature $\left(28 \pm 2^{\circ} \mathrm{C}\right)$ for 48 hours and the cells were harvested at logarithmic phase using 30 ppt sterile sea water. Optical density of the culture suspension was taken at $540 \mathrm{~nm}$ in a UV-VIS spectrophotometer (Shimadzu UV-1601).OD was adjusted to 1 by appropriate dilution and this suspension was used as the inoculum.

\section{Preparation of media 1) Temperature}

Malt extract broth prepared in sea water (35 ppt) was used for testing the growth of the isolates at different temperature. 2) Salinity: Malt extract broth was prepared in sea water of different salinities $(0,10,20,30,40,50,60,70,80,90$ and 100 ppt). 3) pH: Malt extract broth was prepared in sea water (35 ppt) with different $\mathrm{pH} 3,4,5,6,7,8$ and 9.

\section{Inoculation, incubation and measurement of growth:}

Ten $\mu \mathrm{l}$ of 1 OD yeast cell suspension was inoculated into the malt extract agar tubes prepared in triplicate so that the initial OD of the culture medium was 0.001 . Incubation was done at room temperature $\left(28 \pm 2^{\circ} \mathrm{C}\right)$ for 48 hours in the case of $\mathrm{pH}$ and salinity. Growth was estimated by measuring the optical density at $540 \mathrm{~nm}$ using Shimadzu UV-1601 spectrophotometer

\section{Extraction of melanin}

Melanin was extracted from black yeasts as per Gadd (1982). $1 \mathrm{~N} \mathrm{NaOH}$ was added to the harvested yeast biomass and autoclaved for $20 \mathrm{~min}$ at $121^{\circ} \mathrm{C}$. Then it was centrifuged at $8000 \mathrm{rpm}$ for $10 \mathrm{~min}$ and the supernatant (melanin) was separated. Melanin was then precipitated by adding conc. $\mathrm{HCl}$ until $\mathrm{pH} 2$ and again centrifuged at 10,000 rpm for $10 \mathrm{~min}$. This was washed repeatedly with distilled water and dried in a lyophilizer.

\section{Characterization of melanin from black yeasts}

Two-dimensional NMR spectroscopy analysis i.e., Correlation spectroscopy (COSY) and Total correlation spectroscopy (TOCSY) of the melanin extracted from the Black yeast isolates were done at Eastman Chemical Company, USA. The melanin samples were dissolved in $1 \mathrm{M}$ $\mathrm{NaOH}$ by heating to $80^{\circ} \mathrm{C}$. All the NMR spectra were obtained at ambient temperature on a JOEL Eclipse+ 600 NMR spectrophotometer operating at a proton observation frequency of 600.1723 MHz using $5 \mathrm{~mm}$ OD NMR tubes. 1D NMR spectra were collected with the following parameters: sweep width $=15 \mathrm{ppm}$, centre band $=5 \mathrm{ppm}, 32768$ complex points, acquisition time $=3.637 \mathrm{sec}$, spectral resolution $=0.275 \mathrm{~Hz}$, scans $=64,90^{\circ}$ pulse and relaxation delay $=15 \mathrm{sec}$. The COSY 2D spectrum was obtained in absolute-value mode a pulse field gradient experiment using 521x 128 complex points zero filled 1- time in the $\mathrm{y}$ - dimension to give a final 512x 512 data matrix, sweep width $=10 \mathrm{ppm}$, centre band $=5 \mathrm{ppm}$, pre scans $=4$, scans $=8, X$ spectral resolution $=11.7 \mathrm{~Hz}, \mathrm{Y}$ spectral resolution $=46.9 \mathrm{~Hz}$ and relaxation delay= $1 \mathrm{sec}$. The 2D TOCSY NMR spectrum was obtained using the same parameters except for the following: scans $=32$, spin lock time $=100 \mathrm{~m}$ sec and relaxation delay $=2 \mathrm{sec}$. The 2D NOESY NMR spectrum was obtained in phase- sensitive mode using the same parameters except for the following: scans $=32$, mixing time $=100 \mathrm{~m}$ sec and relaxation delay $=2 \mathrm{sec}$.

\section{Antibacterial activity of melanin}

Inhibitory activity of melanin against bacteria was checked by Kirby-Bauer disc diffusion method. Bacterial strains maintained at the National Centre for Aquatic Animal Health (NCAAH) were used for the study. The human and fish pathogens used for the study were Edwardsiella tarda, Aeromonas hydrophila, Vibrio harveyi, V. proteolyticus, $V$. fluvialis, $V$. cholerae, $V$. parahaemolyticus, E. coli, Pseudomonas aeruginosa, Bacillus cereus, Staphylococcus aureus, Streptomyces lividans and Arthrobacter sp. Melanin extracted from the black yeast isolates were suspended in distilled water and used for testing the antibacterial property. Nutrient agar (peptone $0.5 \mathrm{~g}$; beef extract $0.3 \mathrm{~g}$; sea water $(50 \%) 100 \mathrm{ml}$; $\mathrm{pH} 7.2)$ plates were prepared and swab 
inoculation of the pathogens was made on the surface to produce a lawn culture. Sterile filter paper discs impregnated with melanin were placed immediately on the agar surface; the plates were incubated at room temperature $28 \pm 2{ }^{\circ} \mathrm{C}$ for 24 hours and observed for clearing zone formation.

\section{Extraction of melanin degrading enzyme}

The culture was inoculated in to malt extract broth (malt extract $1.5 \mathrm{~g}$; peptone $0.5 \mathrm{~g}$; sea

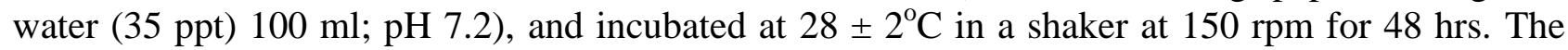
cells were harvested by centrifuging the culture at $8000 \mathrm{rpm}$ and resuspended in a sonicating buffer containing $150 \mathrm{mM} \mathrm{NaCl}, 50 \mathrm{mM}$ Tris and $1 \%$ Triton $\mathrm{X} 100$. The mixture was sonicated for 30 minutes and centrifuged at $8000 \mathrm{rpm}$ for 10 minutes to obtain the supernatant containing the crude enzyme.

\section{Melanin degradation activity:}

To check the activity of melanin degrading enzyme, melanin agar plates (melanin, $1 \%$ agar, $2 \%$, Distilled water, $\mathrm{pH} 8.5$ ) were prepared. Wells of approximately $5 \mathrm{~mm}$ diameter were cut using gel cutter and about $200 \mu \mathrm{l}$ of the crude enzyme was transferred into each well. The plates were incubated at $37^{\circ} \mathrm{C}$ for $48 \mathrm{hrs}$ and the appearance of clearance zone was recorded as positive.

\section{Results}

\section{Occurrence of black yeasts in Bay of Bengal}

Black yeast populations were generally sporadic in the study area. They were found in all depth zones. The population was maximum at Cheyyur i.e., $1.82 \mathrm{cfu} / \mathrm{g}$ dry weight of sediment at $200 \mathrm{~m}$ depth and $1.65 \mathrm{cfu} / \mathrm{g}$ dry weight of sediment at $500 \mathrm{~m}$ depth. Considerable populations were recorded off Karaikkal also at $200 \mathrm{~m}$ depth regions $(0.957 \mathrm{cfu} / \mathrm{g}$ dry weight of sediment). Totally 98 cultures were isolated, streaked on malt extract agar plates for testing purity and maintained in soft agar (malt extract) vials overlaid with sterile liquid paraffin at $4^{0} \mathrm{C}$ (Fig. 1).

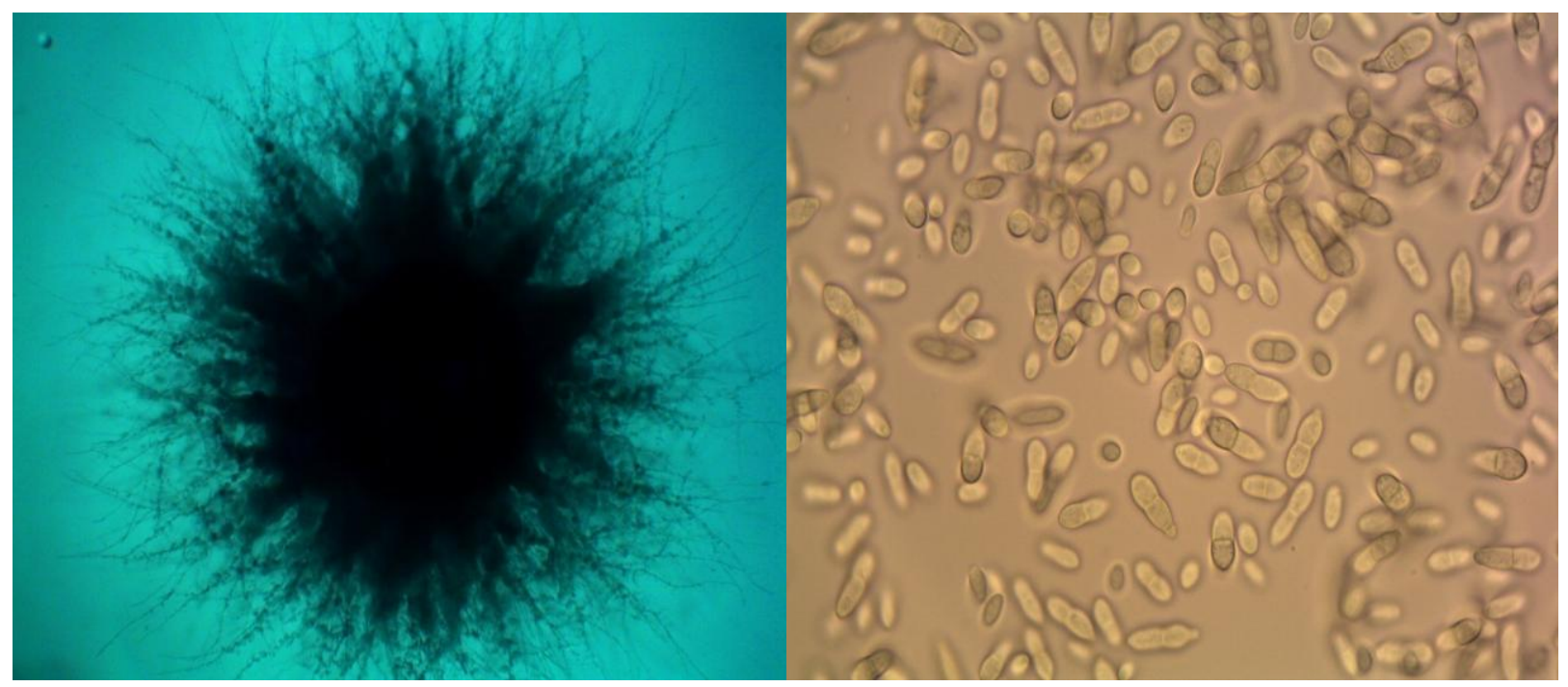

Fig. 1 - Single colony of Black yeast (4X) Wet mount (100 X)

\section{Identification of black yeasts}

Based on the morphological and biochemical characteristics the black yeasts were identified as belonging to the Genus Hortaea. All the isolates showed filamentous growth (Table 1). ITS sequencing and NCBI- BLAST analysis showed that the 10 isolates belonged to Hortaea wernickii (Table 2). ITS sequences of five closely related black yeasts were downloaded from the NCBI GenBank and the multiple alignments were done. A phylogenetic tree was constructed with the 
neighbor joining algorithm with 1000 bootstrap replicates in the MEGA 4.1 package (Fig. 2). The tree shows two monophyletic clades, one clade with 5 isolates SD 480, SD 440, SD 454, SD 378 and SD 429 having 99\% similarity with that of the NCBI strains AB087201 Hortaea werneckii and FJ770076 Dothideales sp. HLS305. Another clade with remaining five isolates SD 483, SD 449, SD 416, SD 430 and SD 450 having 99\% similarity with the NCBI strains FJ755827 Hortaea sp. F47 and EU497947 Dothideales sp. F6. A marine black yeast AJ238676 Trimmatostroma salinum belonging to different genus but same order i.e., Dothideales, was taken as an out-group to show the extent of similarity between the isolates. The consensus distance tree places these isolates SD 378, SD 416, SD 429, SD 430, SD 440, SD 449, SD 450, SD 454, SD 480 and SD 483, in the Hortaea werneckii monophyletic cluster with 99\% similarity, strongly suggesting that all the isolates belong to Hortaea werneckii. The analysis of similarity matrix showed that all the isolates shared almost $100 \%$ similarity with a minor difference in the genetic distance ranging from 0.005- 0.009, which is considered negligible when compared with the difference in the distance shown by the out group (T. salinum) of almost 0.3 . This matrix shows that the 10 isolates share great genetic relatedness among themselves and also the GenBank strains, FJ770076 Dothideales sp. HLS305, AB087201 $H$. werneckii, FJ755827 Hortaea sp. F47 and EU497947 Dothideales sp. F6.

\section{Characteristics of the black yeasts}

All the isolates were able to produce lipase, protease and amylase. About $60 \%$ of the isolates were able to produce ligninase and $40 \%$ produced urease (Fig. 3). The isolates had maximum growth at $30^{\circ} \mathrm{C}$ followed by $20,40,10$ and $50^{\circ} \mathrm{C}$ (Fig. 4.a). All the isolates showed maximum growth at salinity between 30 and 60 ppt (Fig. 4.b). The isolates had maximum growth at pH 8 (Fig. 4.c).

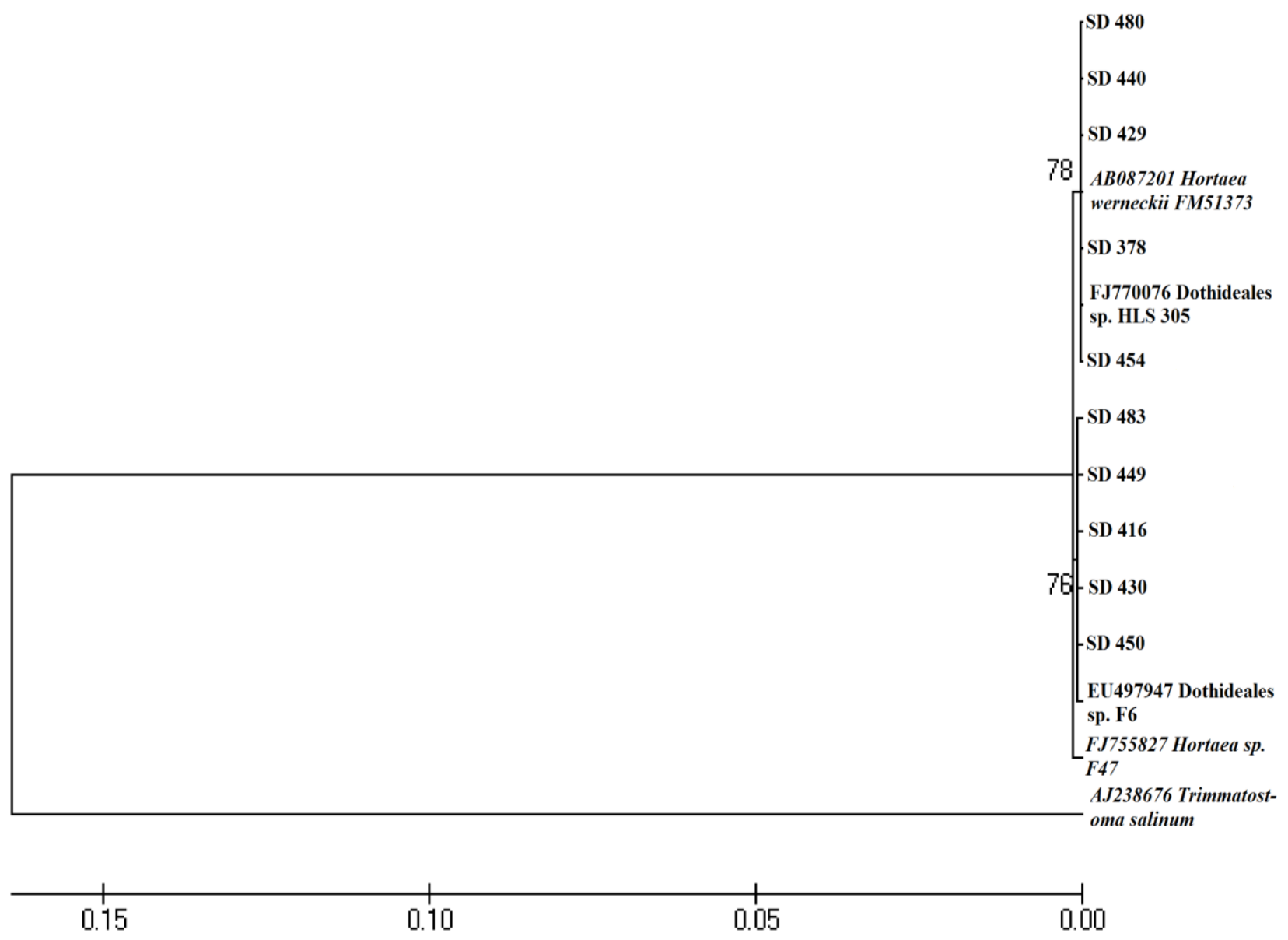

Fig. 2 - Phylogenetic tree based on NJ method 
Table 1 Characteristics of black yeasts

\begin{tabular}{|c|c|c|c|c|c|c|c|c|c|c|c|}
\hline \multirow{2}{*}{ Isolates } & \multicolumn{2}{|c|}{ Location } & \multirow{2}{*}{$\begin{array}{l}\text { Depth } \\
\text { (m) }\end{array}$} & \multirow{2}{*}{$\begin{array}{c}\text { Asexual } \\
\text { reproduction } \\
\end{array}$} & \multirow{2}{*}{$\begin{array}{c}\text { Filamentous } \\
\text { growth }\end{array}$} & \multirow{2}{*}{ MOF } & \multirow{2}{*}{ Lipase } & \multirow{2}{*}{ Amylase } & \multirow{2}{*}{ Protease } & \multirow{2}{*}{ Ligninase } & \multirow{2}{*}{ Urease } \\
\hline & Lat & Long & & & & & & & & & \\
\hline SD 378 & $19^{\circ} 05^{\prime}$ & $85^{\circ} 39^{\prime}$ & 1000 & Budding & + & Oxidative & + & + & + & + & - \\
\hline SD 416 & $10^{\circ} 34^{\prime}$ & $80^{\circ} 26^{\prime}$ & 200 & $\begin{array}{l}\text { Budding/ } \\
\text { Splitting }\end{array}$ & + & Oxidative & + & + & + & - & + \\
\hline SD 429 & $10^{\circ} 34^{\prime}$ & $80^{\circ} 26^{\prime}$ & 200 & $\begin{array}{l}\text { Budding/ } \\
\text { Splitting }\end{array}$ & + & Oxidative & + & + & + & + & - \\
\hline SD 430 & $10^{\circ} 34^{\prime}$ & $80^{\circ} 26^{\prime}$ & 200 & $\begin{array}{l}\text { Budding/ } \\
\text { Splitting }\end{array}$ & + & Oxidative & + & + & + & + & - \\
\hline SD 440 & $11^{\circ} 31^{\prime}$ & $79^{\circ} 59^{\prime}$ & 200 & Budding & + & Oxidative & + & + & + & - & - \\
\hline SD 449 & $14^{\circ} 10^{\prime}$ & $80^{\circ} 27^{\prime}$ & 200 & $\begin{array}{l}\text { Budding/ } \\
\text { Splitting }\end{array}$ & + & Oxidative & + & + & + & + & + \\
\hline SD 450 & $14^{\circ} 10^{\prime}$ & $80^{\circ} 27^{\prime}$ & 200 & $\begin{array}{l}\text { Budding/ } \\
\text { Splitting }\end{array}$ & + & Oxidative & + & + & + & - & + \\
\hline SD 454 & $16^{\circ} 00^{\prime}$ & $82^{\circ} 03^{\prime}$ & 1000 & $\begin{array}{l}\text { Budding/ } \\
\text { Splitting }\end{array}$ & + & Oxidative & + & + & + & + & - \\
\hline SD 480 & $14^{\circ} 10^{\prime}$ & $80^{\circ} 26^{\prime}$ & 500 & $\begin{array}{l}\text { Budding/ } \\
\text { Splitting }\end{array}$ & + & Oxidative & + & + & + & - & + \\
\hline SD 483 & $13^{\circ} 09^{\prime}$ & $80^{\circ} 41^{\prime}$ & 500 & $\begin{array}{l}\text { Budding/ } \\
\text { Splitting }\end{array}$ & + & Oxidative & + & + & + & + & - \\
\hline
\end{tabular}


Table 2 GenBank accession of ITS sequence data

\begin{tabular}{ccc}
\hline Isolate No. & Genus/Species & GenBank Accession No. \\
\hline SD 378 & Hortaea werneckii & GQ334383 \\
SD 416 & Hortaea werneckii & GQ334384 \\
SD 429 & Hortaea werneckii & GQ334385 \\
SD 430 & Hortaea werneckii & GQ334386 \\
SD 440 & Hortaea werneckii & GQ334387 \\
SD 449 & Hortaea werneckii & GQ334388 \\
SD 450 & Hortaea werneckii & GQ334389 \\
SD 454 & Hortaea werneckii & GQ334390 \\
SD 480 & Hortaea werneckii & GQ334331 \\
SD 483 & Hortaea werneckii & \\
\hline
\end{tabular}

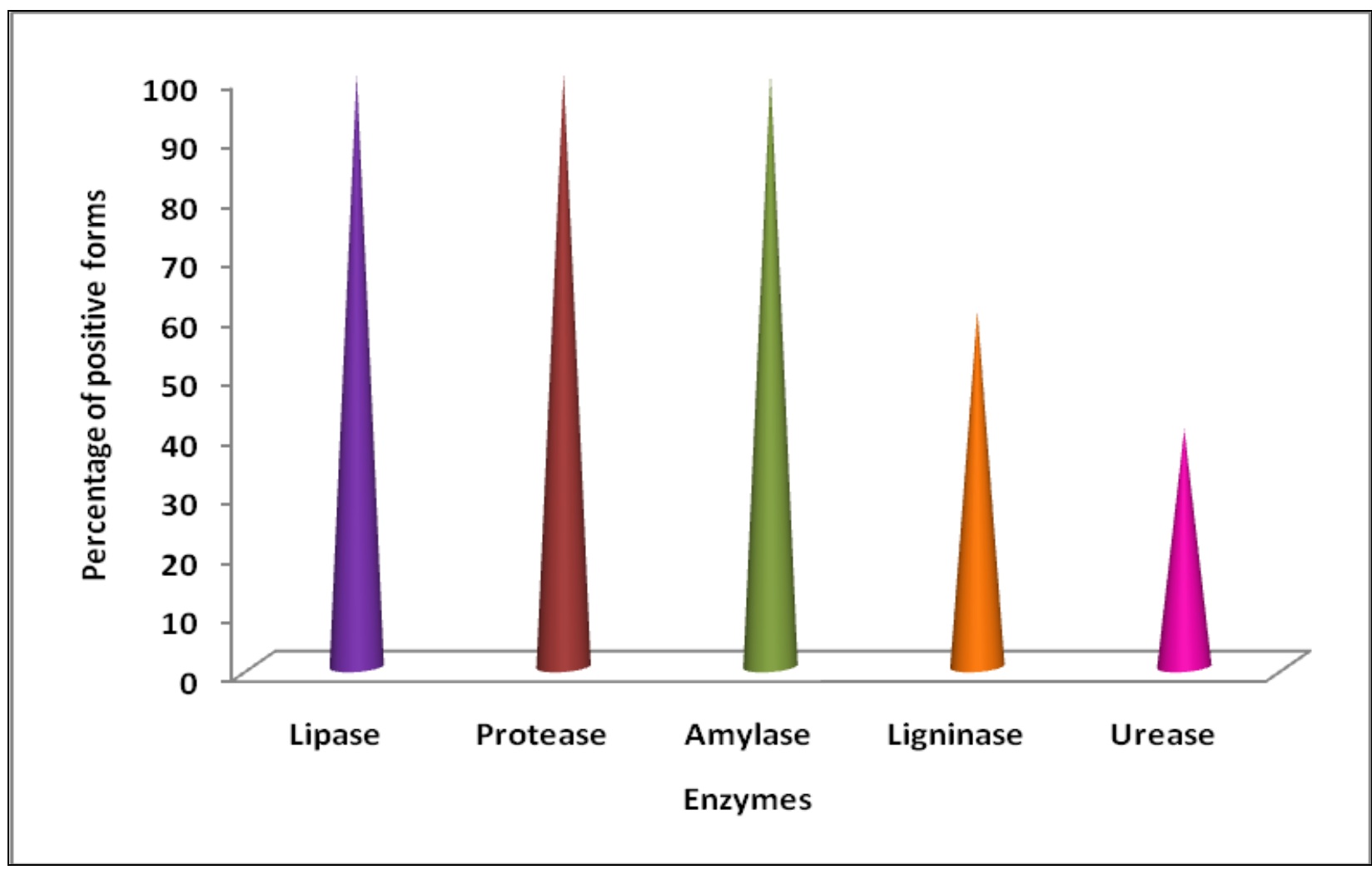

Fig. 3 - Hydrolytic enzyme production by black yeasts

\section{Melanin characterization}

NMR spectroscopy was done for all the melanin samples extracted from the 10 black yeast isolates. It was found that the melanin samples were of 1,8-dihydroxynaphthalene (DHN) type (Fig. 5). From these proton NMR spectra, each melanin isolate was found to contain varying amounts of lipids and carbohydrate. The lipid fraction is indicated by the COSY and NOESY cross peaks between the olefinic proton resonance at $5.3 \mathrm{ppm}$ and the aliphatic resonances between 2.5 and 0.5 ppm. These resonances are characteristic of a long chain aliphatic acid containing 1 olefinic bond. The two sharp aromatic resonances at 6.8 and $7.2 \mathrm{ppm}$ are coupled from the COSY spectrum so are in the same para-substituted aromatic ring spin system. This assignment is supported by a correlation from the NOESY spectrum between the resonance at $6.81 \mathrm{ppm}$ and the resonance at $4.09 \mathrm{ppm}$ assigned to the alpha methylene group in the first ethylene oxide repeat unit of a polyethylene oxide chain attached to an aromatic ring. A weaker NOESY correlation connects to the beta methylene group of the first ethylene oxide repeat unit. More evidence for the assignment 
comes from a correlation between the aromatic resonance at $7.23 \mathrm{ppm}$ and aliphatic resonances at 1.3 and $1.7 \mathrm{ppm}$. The aromatic resonance region of each isolate spectrum shows the two rather sharp resonances just discussed and three broader resonances at 6.55, 6.95 and about $7.3 \mathrm{ppm}$. These resonances resemble resonances from indole or pyrrole structural units previously reported for melanin isolated from human hair.
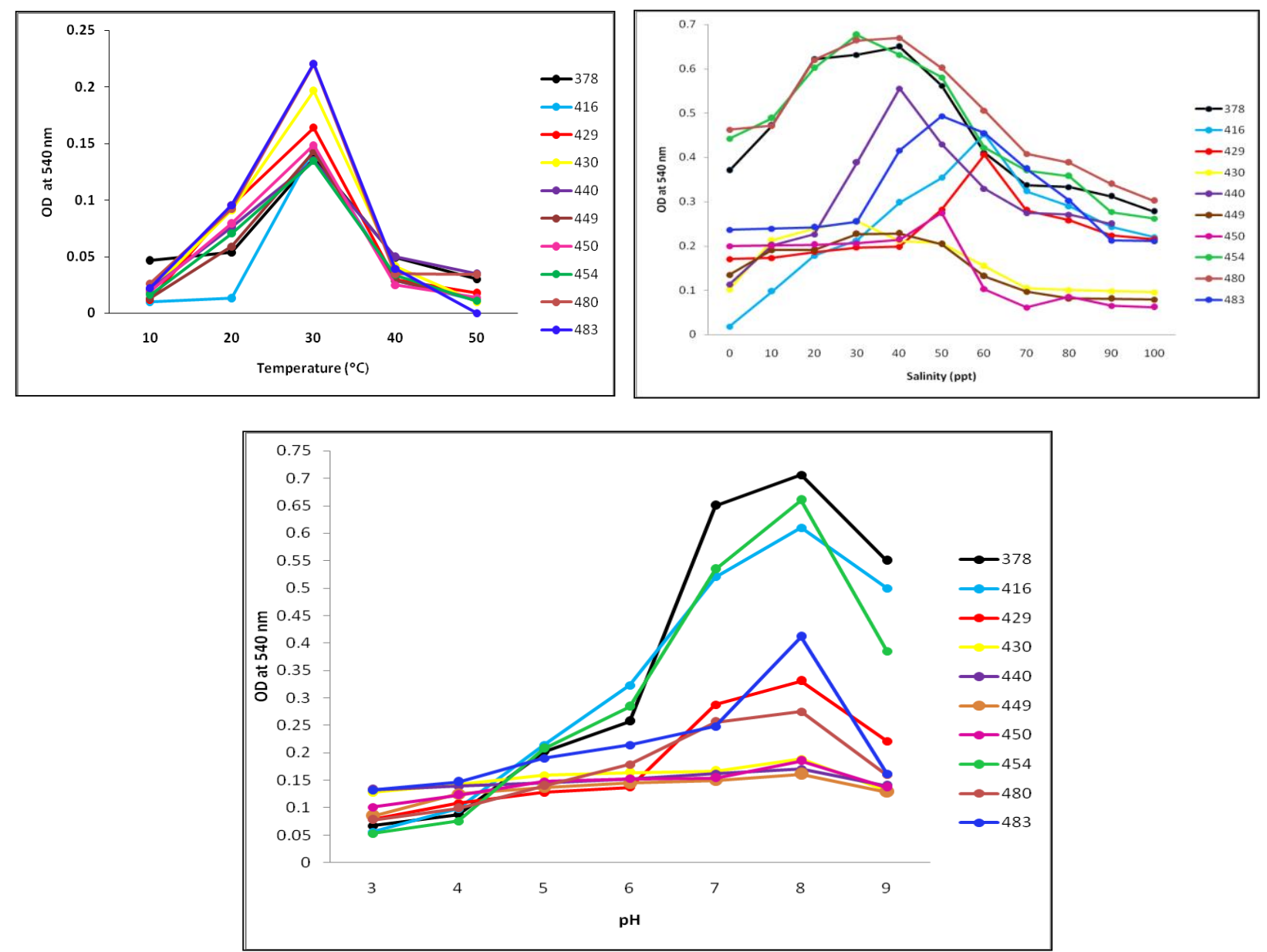

Fig. 4 - Optimum temperature, salinity and $\mathrm{pH}$ for the growth of black yeast isolates

Integral areas of the resonances at 6.95 and $6.55 \mathrm{ppm}$ in melanin are shown in the Table 3. The resonance at $6.95 \mathrm{ppm}$ is assigned to DHN while that at $6.55 \mathrm{ppm}$ is assigned to indole structures. The relative amounts of DHN and Indole structures are shown in the columns labeled "DHN" and "Indole" below. Generally, these melanin isolates contain roughly 10-19\% DHN with remaining $90-81 \%$ being Indole repeat units. The molar ratio of Indole to DHN is highest for SD 416 at 9.3, followed by SD 483 at 6.9, then SD 440 at 5.6, with 5 samples - SD 378, SD 429, SD 430, SD 454 and SD 480 falling in the intermediate molar ratio range of 5.1 down to 4.7 and finally the lowest ratio for SD 449 and SD 450 with roughly equal ratios at 4.2.

\section{Antibacterial activity of melanin}

Melanin extracted from the black yeasts was found to have activity against almost all the human and fish pathogens tested (Fig. 6). Inhibitory activity was comparatively high against Streptomyces lividans, Edwardsiella tarda, Escherichia coli and Staphylococcus aureus (Table 4). 
Table 3 Integral areas of the resonances at 6.95 and $6.55 \mathrm{ppm}$ in melanins and relative amounts of DHN \& Indol

\begin{tabular}{llcccc}
\hline Sample & DFILE & $\mathbf{6 . 9 5} \mathbf{~ p p m}$ & $\mathbf{6 . 5 5}$ & DHN (\%) & Indole (\%) \\
\hline SD 378 & $\mathrm{d} 57175$ & 0.94 & 2.42 & 16 & 84 \\
SD 416 & $\mathrm{d} 57176$ & 0.36 & 1.68 & 10 & 90 \\
SD 429 & $\mathrm{d} 57177$ & 1.4 & 3.37 & 17 & 83 \\
SD 430 & $\mathrm{d} 57178$ & 2.06 & 4.8 & 18 & 82 \\
SD 440 & $\mathrm{d} 57179$ & 0.93 & 2.62 & 15 & 85 \\
SD 449 & $\mathrm{d} 57180$ & 0.95 & 1.99 & 19 & 81 \\
SD 450 & $\mathrm{d} 57181$ & 0.68 & 1.43 & 19 & 81 \\
SD 454 & $\mathrm{d} 57182$ & 1.31 & 3.05 & 18 & 82 \\
SD 480 & $\mathrm{d} 57183$ & 1.41 & 3.53 & 17 & 83 \\
SD 483 & $\mathrm{d} 57186$ & 0.49 & 1.69 & 13 & 87 \\
\hline
\end{tabular}

\section{Melanin degrading enzyme}

The crude enzyme extracted from black yeasts was found to have activity against the melanin extracted from the black yeasts. The enzyme was found to produce clearance zone in melanin agar plates (Fig. 7).

Table 4 Antibacterial activity of melanin against pathogens

\begin{tabular}{|c|c|c|c|c|c|c|c|c|c|c|}
\hline Pathogens & SD378 & SD416 & SD429 & SD430 & SD440 & SD449 & SD450 & SD454 & SD480 & SD483 \\
\hline $\begin{array}{l}\text { Streptomyces } \\
\text { lividans }\end{array}$ & ++ & ++ & ++ & ++ & ++ & ++ & + & ++ & ++ & + \\
\hline $\begin{array}{l}\text { Edwardsiella } \\
\text { tarda }\end{array}$ & ++ & + & ++ & ++ & ++ & + & ++ & ++ & ++ & - \\
\hline $\begin{array}{l}\text { Aeromonas } \\
\text { hydrophila }\end{array}$ & - & - & + & + & + & + & + & ++ & + & + \\
\hline Vibrio harveyi & + & - & - & + & + & + & + & + & + & - \\
\hline V. proteolyticus & + & - & - & + & + & + & + & + & + & - \\
\hline V. fluvialis & + & - & + & + & + & + & + & + & + & - \\
\hline V. cholerae & + & - & + & + & + & + & + & + & + & - \\
\hline $\begin{array}{l}\text { V. } \\
\text { parahaemolyticus }\end{array}$ & + & - & + & + & + & + & + & + & + & - \\
\hline E. coli & + & + & ++ & ++ & + & ++ & + & + & ++ & - \\
\hline $\begin{array}{l}\text { Pseudomonas } \\
\text { aeruginosa }\end{array}$ & + & - & + & ++ & + & - & + & + & ++ & - \\
\hline Bacillus cereus & - & - & - & + & - & + & - & + & + & + \\
\hline $\begin{array}{l}\text { Staphylococcus } \\
\text { aureus }\end{array}$ & ++ & + & ++ & ++ & + & ++ & ++ & ++ & ++ & + \\
\hline Arthrobacter sp. & + & - & + & ++ & + & - & ++ & + & - & - \\
\hline
\end{tabular}




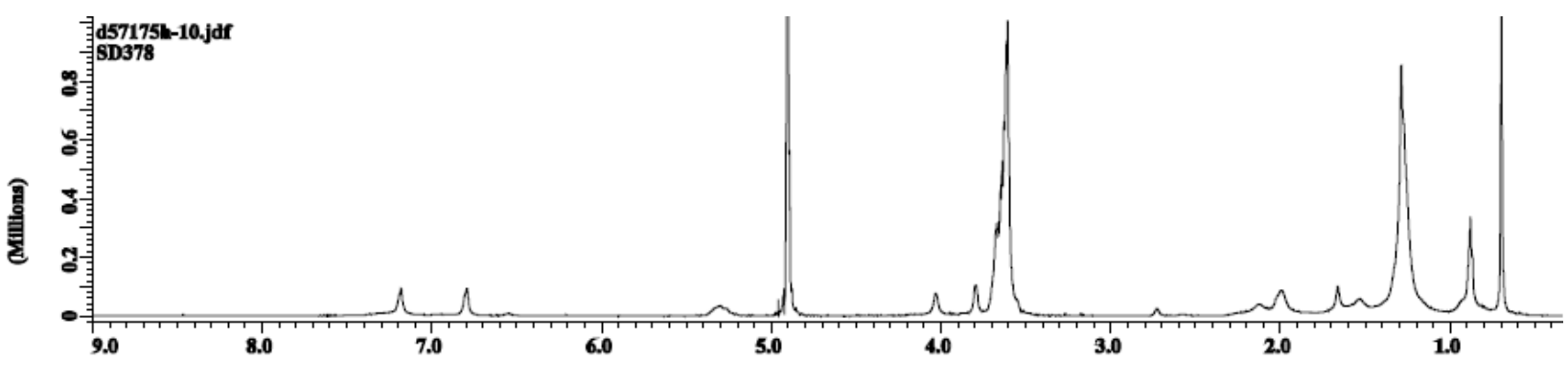

$X$ : parts per Million : $1 H$

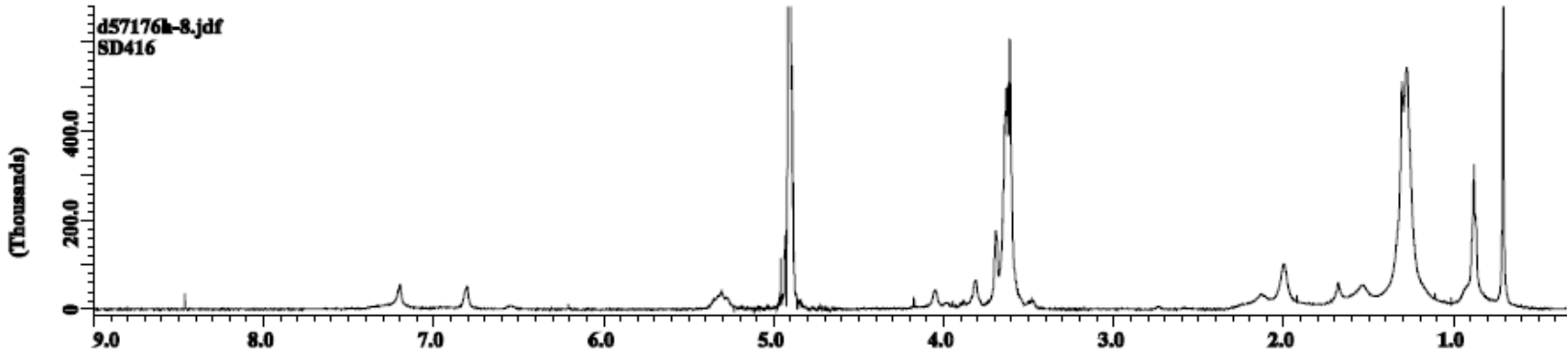

X : parts per Million : $1 H$
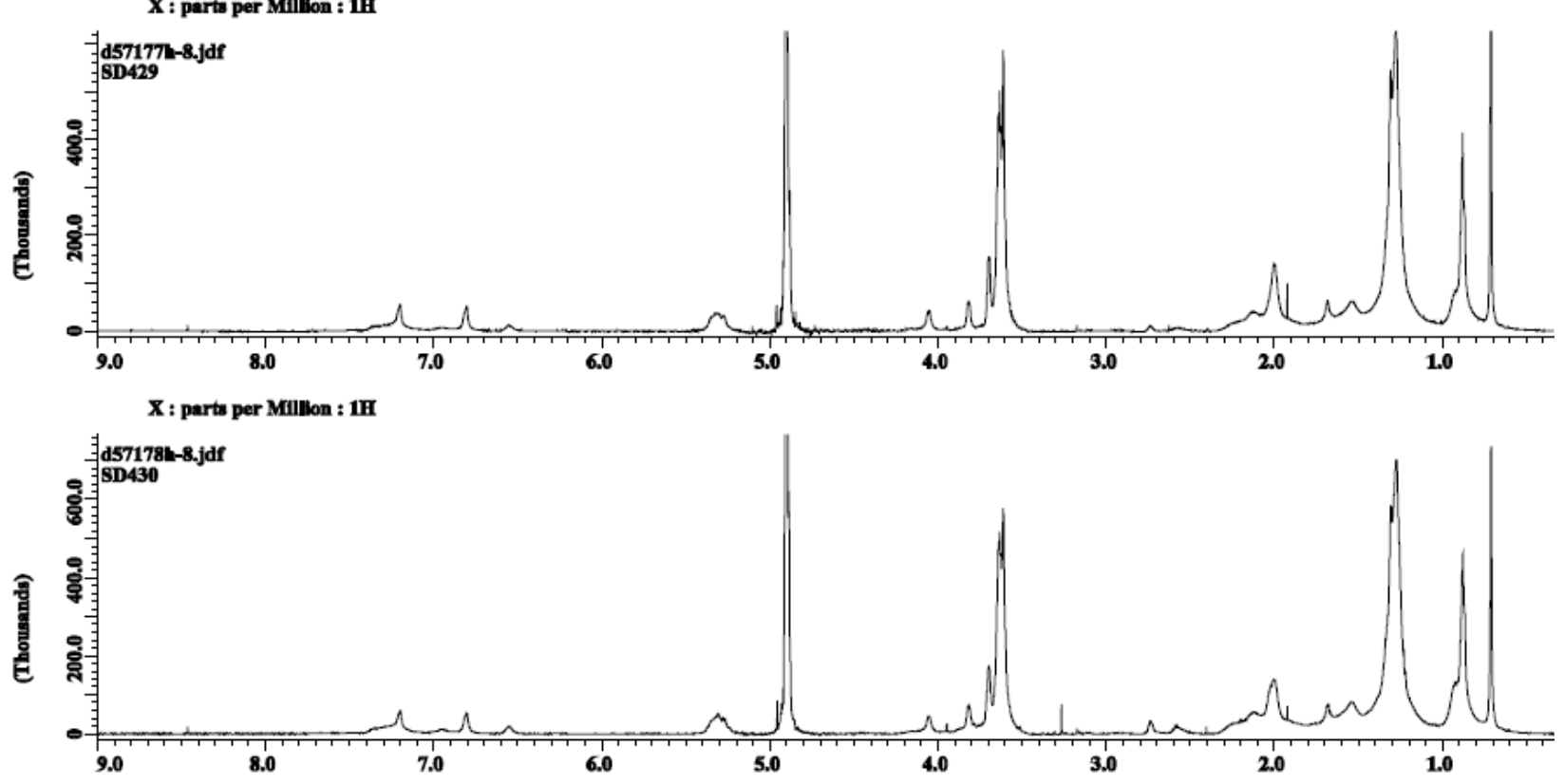

$\mathrm{X}$ : parts per Mellion : $1 \mathrm{H}$

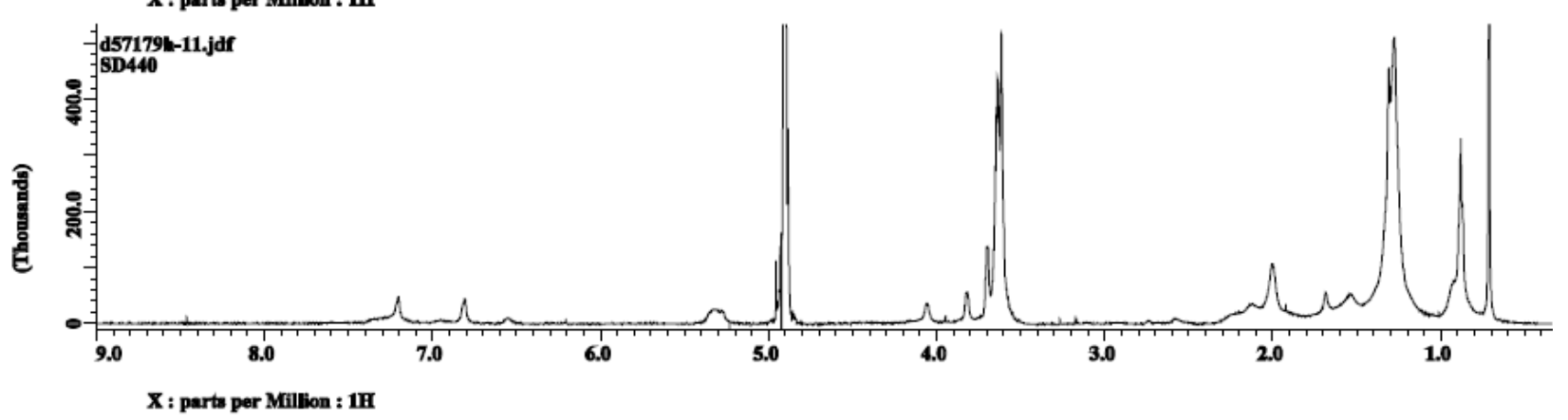

Fig. 5 - Complete proton NMR spectra of the melanin samples, displayed from about 9.0 to 0.3 ppm 

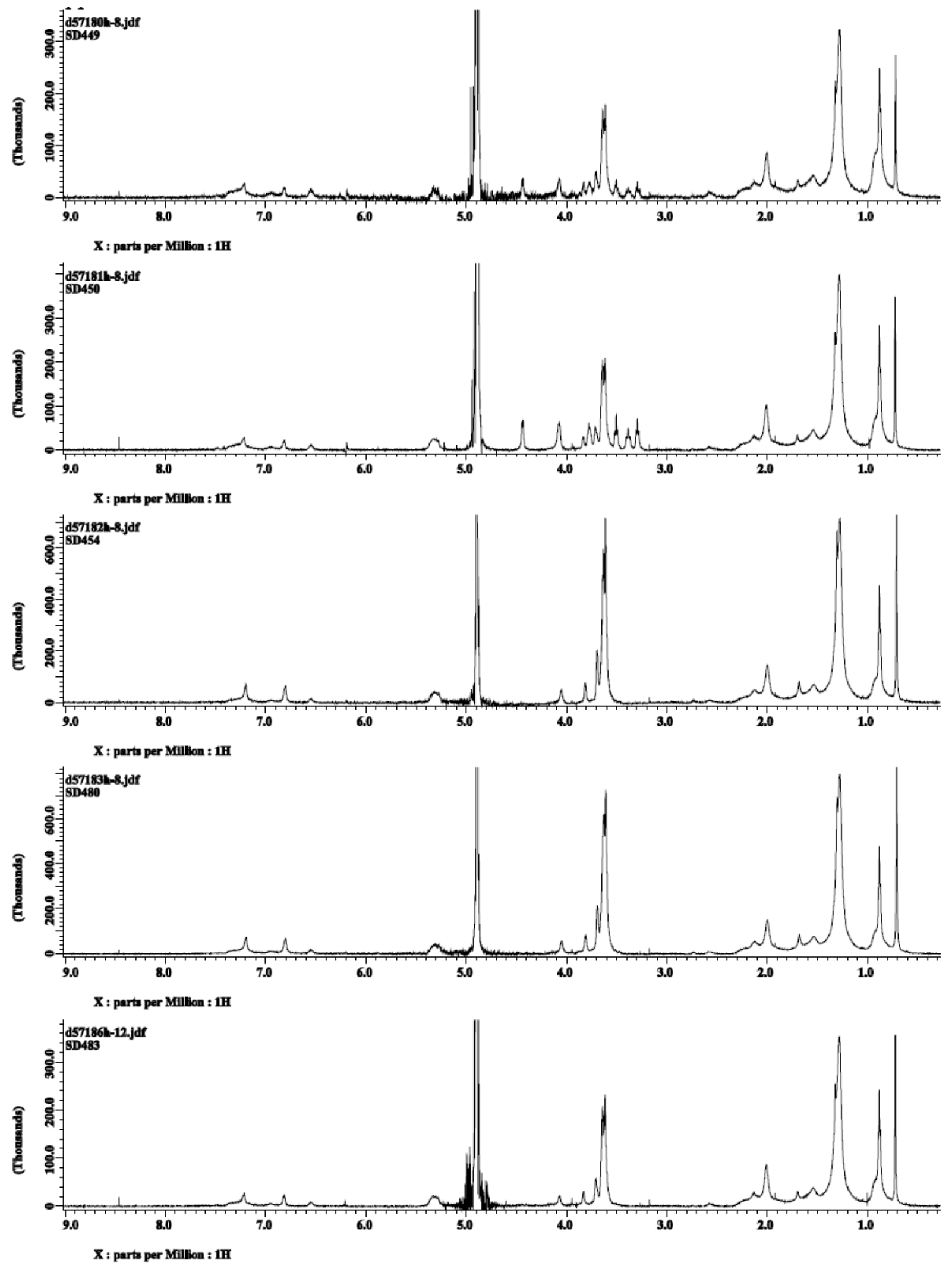

Fig. 5 - cont. Complete proton NMR spectra of the remaining 5 melanin samples, displayed from about 9.0 to $0.3 \mathrm{ppm}$ 


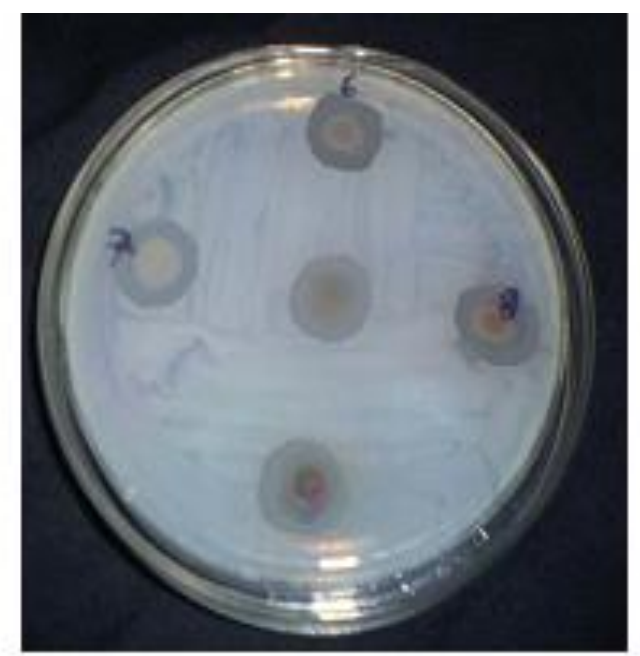

a E. coli

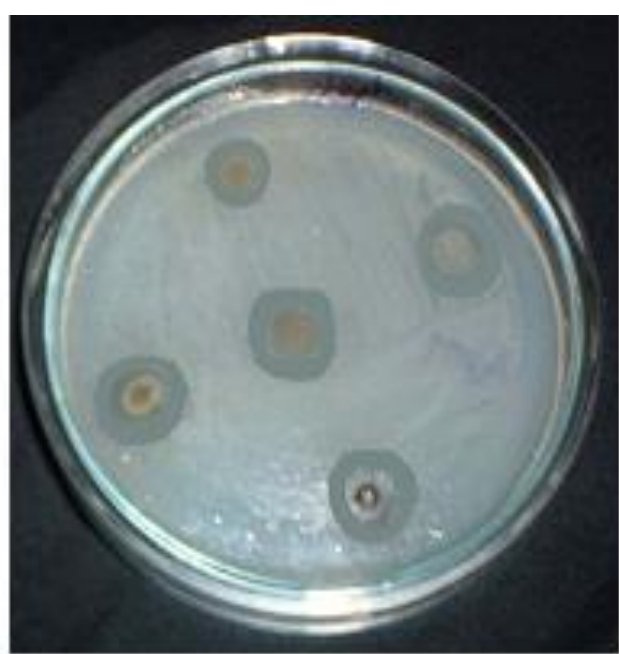

b Staphylococcus aureus

Fig. 6 - Antibacterial activity of melanin extracted from black yeasts

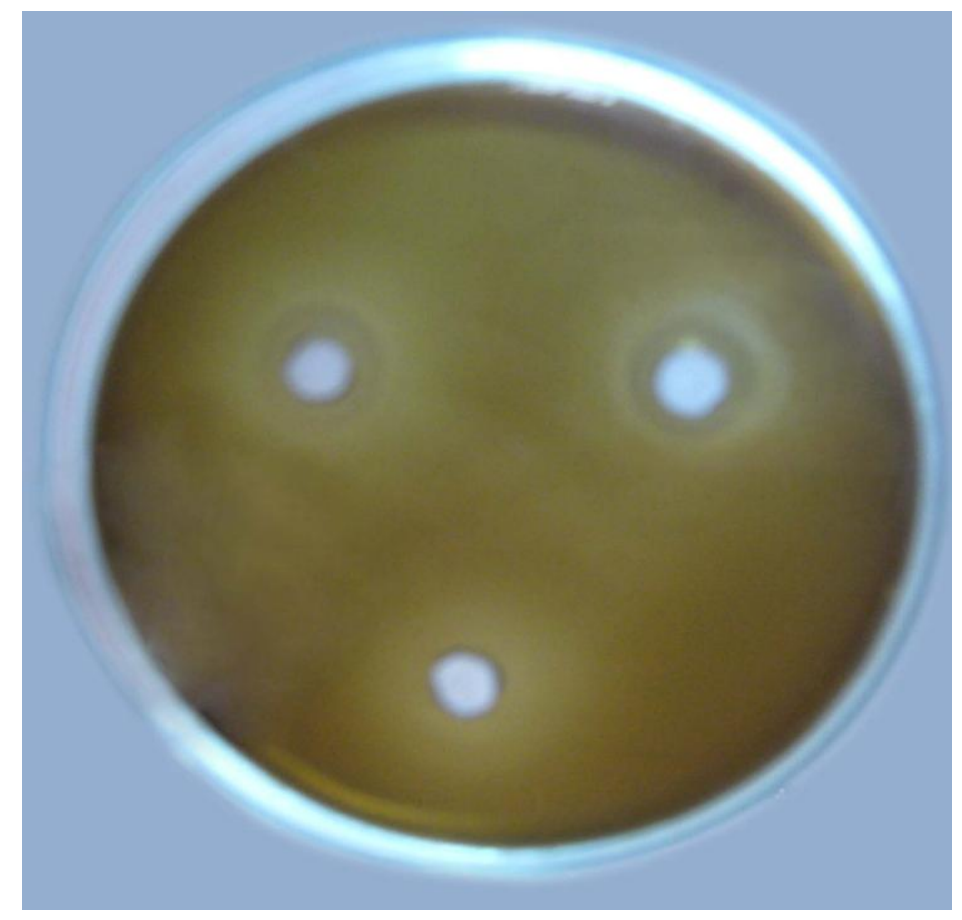

Fig. 7 - Clearance zone showing the degradation of melanin by melanin degrading enzyme

\section{Discussion}

Black yeasts are characterized by very slow growth at ambient conditions. All the isolates showed filamentous growth and were oxidative in nature. It has already been shown that all black yeasts are aerobic; having an oxidative metabolism, no fermentation of sugars has been observed (Rosa and Peter, 2006). All the isolates reproduced asexually by budding and they belonged to the Division Ascomycota and Order Dothideales. The overall phylogeny of black yeasts is a complex task and needs a polyphasic approach (Rosa and Peter, 2006). So Internal Transcribed Spacer (ITS) sequencing was used for identification of black yeasts. Neighbour joining (NJ) tree was constructed to determine the relationship between the isolates and five other strains of black yeasts from NCBI 
including the strain, Trimmatostroma salinum which was taken as the out group. The NJ tree placed the black yeast isolates SD 378, SD 416, SD 429, SD 430, SD 440, SD 449, SD 450, SD 454, SD 480 and SD 483, in the Hortaea werneckii monophyletic cluster with $99 \%$ similarity. The analysis of similarity matrix in MEGA 4.1 package showed that all the isolates shared about $100 \%$ similarity.

Enzymes from yeasts are found to be useful in various industrial processes which emphasize their contribution (Kutty and Philip, 2008). These enzymes are produced mostly extracellular by different metabolic reactions taking place inside the cell and participate in various transformation activities like mineralization of organic compounds. Studies by Paskevicus (2001) showed that almost all the yeast strains produce lipase. Lipases catalyse a wide range of reactions like hydrolysis, esterification, alcoholysis, acidolysis and aminolysis etc. (Hasan et al., 2006). Lipases are mainly involved in detergent industry and biodegradation, especially oil residues. Protease has many applications in detergent, leather processing and feed industry besides waste treatment (Ni et al., 2008). Yeast amylases have many applications in bread and baking industry, starch liquefaction and saccharification, paper industry, detergent industry, medical and clinical analysis, food and pharmaceutical industries (Chi et al., 2003; Gupta et al., 2003). Amylolytic yeasts convert starchy biomass to single cell protein and ethanol ( $\mathrm{Li}$ et al., 2006). The isolates were potent agents of biodegradation as they were able to produce lipase, protease, amylase, ligninase and urease. There are reports on black yeasts producing extra cellular glucans which is commercially used in human diet as immunostimulant. Japanese have commercialized a glucan from the black yeast like fungus, Aureobasidium pullulans, as AUREO (www.aureo.co.jp). The production of glucan like extracellular products needs to be studied in detail.

All the isolates had their maximum growth at $30^{\circ} \mathrm{C}$; however, they showed considerable growth at $20^{\circ} \mathrm{C}$ also. The growth of black yeasts from nature is limited to temperatures below $32^{\circ} \mathrm{C}$, where as phylogenetically related species which are agents of human infections may grow at temperatures up to $37^{\circ} \mathrm{C}$. For physiologically active and fully hydrated colonies, the lethal temperature is between 35 and $75^{\circ} \mathrm{C}$, but dehydrated colonies can withstand up to $120^{\circ} \mathrm{C}$ which when transferred to fresh medium retains growth (Sterflinger, 1998). The isolates in the present study showed maximum growth at salinities between 30 and $60 \mathrm{ppt}$ and considerable growth up to $100 \mathrm{ppt}$. This proves the halophilic nature of these organisms and the fact that they are excellent eukaryotic counter parts for studies regarding salt tolerance (Kogej et al., 2005).

The melanin extracted from the isolates was confirmed to be of di-hydroxynaphthalene (DHN) type. Bell and Wheeler (1986) reported that the members of the class Ascomycetes synthesize DHN type melanin. The melanin extracted was found to be complexed with lipid components. Melanin formed by DHN pathway is reported to protect these organisms against a number of environmental factors, which attests to their protective properties. The melanin also exhibits an osmoprotectant role enabling the organism to flourish in hypersaline conditions. Melanin preparations are widely used in dermatology and cosmetology and possess antioxidant activities. The melanin confers different properties to the organisms which prove their efficiency against pathogenic microbes (Casadevall et al., 2000). The pigment was found to have antagonistic activity against different fish and human pathogens. This proves the importance of melanin in defence apart from their protective effect to thrive under adverse and extreme conditions. Conditions for maximum production of the pigment need to be optimized for large scale production and commercial applications.

More studies need to be done on characterization of these organisms for industrial applications. Report on the isolation of these organisms from sea water or other environments are very few except those from hypersaline waters. According to the present study, these black yeast isolates identified as Hortaea werneckii are highly versatile in biodegradation besides being a potent source of melanin. Halophilic nature can be exploited for their utilization as eukaryotic model in salt tolerance and adaptation studies. Since the black yeasts survive dehydration and 
tolerate high temperature retaining the physiological activities; being endowed with wide spectrum hydrolytic potential, these are potential candidates for various industrial applications.

\section{Acknowledgement}

The authors are thankful to the Director, CMLRE, Ministry of Earth Sciences, Government of India for the sample collection and the first author is thankful to University Grant Commission for financial support.

\section{References}

Altschul SF, Gish W, Miller W, Myers EW, Lipman DJ. 1990 - Basic local alignment search tool. Journal of Molecular Biology 215, 403-410.

Bell AA, Wheeler MH. 1986 - Biosynthesis and functions of fungal melanins. Annual Review of Phytopathology 24, 411-451.

Butler MJ, Gardiner RB, Day AW. 2005 - Degradation of melanin or inhibition of its synthesis: are these a significant approach as a biological control of phytopathogenic fungi? Biological Control 32, 32-336.

Casadevall A, Rosas AL, Nosanchuk JD. 2000 - Melanin and virulence in Cryptococcus neoformans. Current Opinion in Microbiology 3, 354-358.

Chi Z, Liu Z, Gong F. 2003 - Marine yeasts and their applications in mariculture: Perspectives. National Conference on Marine High Biotechnology, 440-450.

De Hoog GS. 1993 - Evolution of Black yeasts: possible adaptation to human host. Antonie van Leeuwenhoek 63, 105-109.

De Hoog GS, McGinnis MR. 1987 - Ascomycetous black yeasts. Studies in Mycology 30, 187199.

Gadd GM. 1982 - Effects of media composition and light on colony differentiation and melanin synthesis in Microdochium bolleyi. Transactions of the British Mycological Society 78, $115-122$.

Gunde Cimerman N, Plemenitas A. 2006 - Ecology and molecular adaptations of the halophilic black yeast Hortea werneckii. Reviews in Environmental Science and Biotechnology 5, 323-331.

Gunde Cimerman N, Zalar P, De Hoog GS, Plemenitas A. 2000 - Hypersaline waters in salterns natural ecological niches for halophilic black yeasts. FEMS Microbiology Ecology 32, 235240.

Gupta R, Gigras P, Mohapatra H, Goswami VK, Chauhan B. 2003 - Microbial amylase: a biotechnological perspective. Process Biochemistry 38, 1599-1616.

Harju S, Fedosyuk H, Peterson KR. 2004 - Rapid isolation of yeast genomic DNA: Bust n' Grab. BMC Biotechnology 4, 8 .

Hasan F, Shah AA, Hameed A. 2006 - Industrial applications of microbial lipases. Enzyme and Microbial Technology 39, 235-251.

Kogej T, Gorbushina AA, Gunde -Cimerman N. 2006 - Hypersaline conditions induce changes in cell-wall melanization and colony structure in a halophilic and a xerophilic black yeast species of the genus Trimmatostroma. Mycological Research 110, 713-7124.

Kogej T, Ramos J, Plemenitas A, Gunde-Cimerman N. 2005 - The halophilic fungus Hortaea werneckii and the halotolerant fungus Aureobasidium pullulans maintain low intracellular cation concentrations in hypersaline enviroments. Applied and Environmental Microbiology $71,6600-6605$.

Kogej T, Stein M, Volkmann M, Gorbushina AA, Galinski EA, Gunde-Cimerman N. 2007 Osmotic adaptation of the halophilic fungus Hortaea werneckii: role of osmolytes and melanization. Microbiology 153, 4261-4273. 
Kogej T, Wheeler MH, Rizner TL, Gunde-Cimerman N. 2004 - Evidence for 1, 8 dihydroxynaphthalene melanin in three halophilic black yeasts grown under saline and nonsaline conditions. FEMS Microbiology Letters 232, 203-209.

Kutty SN, Philip R. 2008 - Marine Yeasts - a review. Yeast 25(7), 465-483.

Kutty S N. 2010 - Marine yeasts from the slope sediments of Arabian Sea and Bay of Bengal. Ph.D. Thesis. Cochin University of Science and Technology, Kochi, Kerala, India.

Li H, Chi Z, Wang X, Duan X, Ma L, Gao L. 2006 - Purification and characteri-zation of extra cellular amylase from the marine yeast Aureobasidium pullulans N13d and its raw potato starch digestion. Enzyme and Microbial Technology 40, 1006-1012.

Ni XM, Chi ZM, Liu ZQ, Yue LX. 2008 - Screening of protease -producing marine yeasts for production of the bioactive peptides. Acta Oceanologica Sinica 27, 116-125.

Nosanchuk JD, Casadevall A. 2006 - Impact of melanin on microbial virulence and clinical resistance to antimicrobial compounds. Antimicrobial Agents and Chemotherapy 50, 35193528.

Paramonov BA, Turkovskii II, Potokin IL, Chebotarev VYu. 2002 - Photoprotective acitivity of melanin preparations from black yeast -like fungus during UV irradiation of human skin: Dependence on the concentration. Bulletin of Experimental Biology and Medicine 133(4), 377-379.

Paskevicius A. 2001 - Lipase activity of yeasts and yeast-like fungi functioning under natural conditions. Biologija 4, 16-18.

Petrovic U, Gunde-Cimerman N, Plemenitas A. 2002 - Cellular responses to environmental salinity in the halophilic black yeast Hortaea werneckii. Molecular Microbiology 45, 665-672.

Plemenitas A, Vaupotic T, Lenassi M, Kogej T, Gunde-Cimerman N. 2008 - Adaptation of extremely halotolerant black yeast Hortea werneckii to increased osmolarity: a molecular perspective at a glance. Studies in Mycology 61, 67-75.

Rosa CA, Peter G. (eds) 2006 - Biodiversity and Ecophysiology of Yeasts. springeronline.com. $561 \mathrm{pp}$.

Saitou N, Nei M. 1987 - The neighbour joining method: a new method for reconstructing phylogenetic trees. Molecular Biology and Evolution 4, 406-425

Sterflinger K. 1998. Temperature and NaCl-tolerance of rock-inhabiting meristematic fungi. Antonie van Leeuwenhoek 74, 271-281.

Suryanarayanan S, Ravishankar JP, Venkatesan G, Murali TS. 2004 - Characterization of melanin pigment of a cosmopolitan fungal endophyte. Mycological Research 108, 974-978.

Tamura K, Dudley J, Nei M, Kumar S. 2007 - MEGA4: Molecular Evolutionary Genetics Analysis (MEGA) software version 4.0. Molecular Biology and Evolution 24, 1596-1599.

Van Uden N, Ahearn DC. 1963 - Occurrence and population densities of yeast species in a fresh water lake. Antonie van Leeuwenhoek 29, 308-312.

Van Uden N, Castelo - Branco R. 1963 - Distribution and population densities of yeast species in Pacific water, air, animals and kelp off Southern California. Limnology and Oceanography $8,323-329$.

White TJ, Bruns T, Lee S, Taylor J. 1990 - Amplification and direct sequencing of fungal ribosomal RNA genes for phylogenetics. PCR Protocols. A guide to methods and applications. (Innis MA, Gelfand DH, Sninsky JJ, White TJ eds), pp. 315-324. Academic press, Inc., San Diego, California.

Zalar P, de Hoog GS, Gunde-Cimerman N. 1999 - Ecology of halotolerant dothideaceous black yeasts. Studies in Mycology 43, 38-48. 